\title{
機械搾乳における真些度制御が推乳効率, 乳質におよぽす影響
}

\author{
鈴 木 健 二 \\ (東京大学農学部) \\ (昭和37年12月12日受付)
}

従来の真空度固定方式による二相搏勤式(吸引・圧縮）

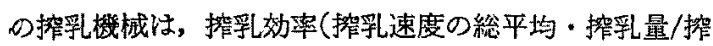
乳時間）法比較的高いが，乳質安低下させる可能性があ ることを，欧米でるみとめている1-8)。三相搏動式 (吸 引・压綰・休息) は, 子牛の吸乳動作飞似ていて, 合理 的であるとソ速で恬評価されているが，㩁乳効率が低 い4).

そとで，これら両式の長所をかねそなえる真空度制御 方式の搾乳法は，搾乳効率を高め，かつ後控量を少なく 乙，脂肪率を高め，細胞数它少なくするのではないかと 考えこれについて，次のような実験を行なつた．乳汁 排出のメカニズムといわれている Neuro-hormonal arc は，一つの䅹条件反射であって，それ自体が生理的恒常 性を稚持するように「自律制御」の機能をるつている。 そこで，控乳装置のほうあ制御し，従来のように乳牛之 無関係认控乳機が作動するのではなく，動物と機械が結 合された形で，全体系にわたる制御によつて，最適の自 己調節を行なるせようとするのが, 本研究の構想であ る. Neuro-hormonal arc の作用は, 吸引刺激によつ て急激に高められ，急速に減退する特性があるそそこで これに平行して，吸引の原動力である真空圧に，正方向 の制御 (Positive feedback control, 結果に対応して, 正の方向に原因を制御する方式）を与えれば，初期の搾 乳ビーク時に最高の初率で㵠乳し，後期では吸引力を制 動し，售乳終期の真空作用を停止することによつて，最 適の控乳ができるであるう。

\section{寒 験 方 法}

1. 使用動物 : 酪農電化センターにけい䓹して搾乳中 のホルスタイン種および隻種 50〜100頭の乳牛から，乳 期と乳量がほぼ等しいるのを選んで実験した。

後にのべる規格式制御方式の場合には，1プロック 3 顸ずつ， 3 プロック合計 9 頭を対象とし，ラテン方格法 によつて，毎日反復交代させて実験した。また個別式制 御方式の場合には，10頭を3ブロッタに分けて毎日害験 し，対照区ではその前後の日に計 2 回行なつた．搾孚は
第 2 回竅乳時（午後 4 時定標集とする）に行なつた.

2. 測乳法および測定法第 1 図のような控乳装置によ

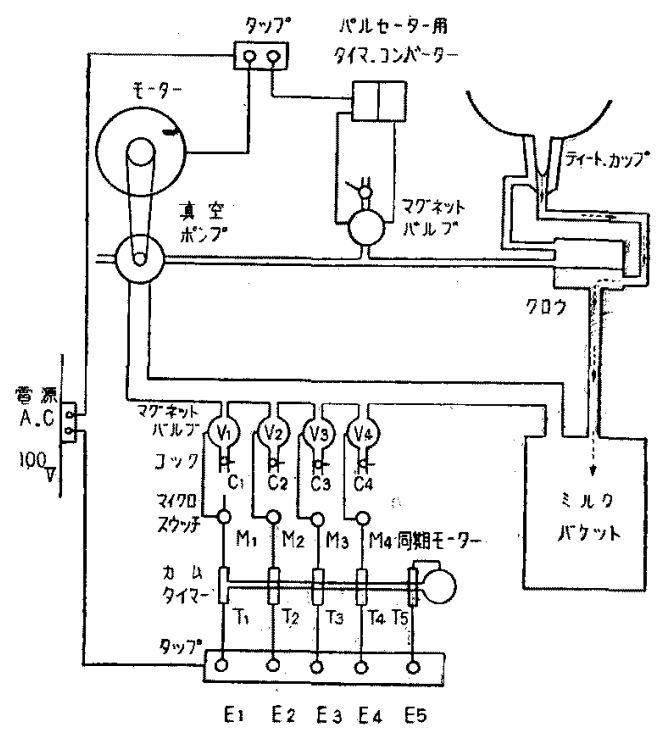

第1図 真空度自動制御用の㩁乳装置

つて㨨乳した。㩁乳速度は，サスペンド式重量計(100 g 目盛, $20 \mathrm{~kg}$ 限界) とストップ・ウオッチ(60秒式)を併 用して測定した. 乳脂率 (0.1\%筆位) は，バブコック法 またはゲルベル法により，乳汁中の細胞数 (万/cc 単位) はプリード法により測定した。

3. 真空度調節法.（1)烧格式の制御方式は，乳牛の個 体差を無視して，一定の型の真空度変圧を適用する方法 がある. 真空度は $40 \mathrm{cmHg}$ で㩁乳を開始し，1分間に $5 \mathrm{cmHg}$ ずつ低下させ，4分後法 $20 \mathrm{cmHg}$ 儿固定して， 摍乳が終了するまで，そのま安とた。乳量の変化に対 して，正の方向に真空度死变圧するので，これをポジテ ィブ制御と呼び，負の方向に真空度を变生する方式衣 ガティブ制御ときめた.(2)個別式の真空度制御方式は乳 牛個体别に差巽のある控乳速度曲線它基準にし, 乳牛個 体ごとに固有の真空度変压を正の方向にあたえるもので 


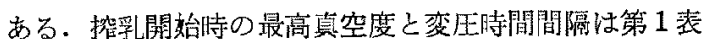
のよらに調節した．次に類似の㩁乳速度型定もつ乳牛定 ダループとし，3種（大，中，小）にわけ，2四の制御 をあた点た。真空チューブのェャー・バルブと, 真空ポ ンプのモーター回転速度調節用スライダックを, 手動で コントロールした. 比較対照区には, 従来の真空度固定

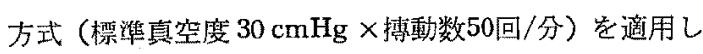
た.

第 1 奉 個別式ポジテブィ御制の調節法

\begin{tabular}{|c|c|c|}
\hline 乳牛 No. & 最高真空度 & 真空潤節間隔時間 \\
\hline 1 & ${ }_{40} \mathrm{Cm} \mathrm{I}$ & $15^{\text {秒 }}$ \\
\hline 2 & 35 & 30 \\
\hline 3 & 45 & 30 \\
\hline 4 & 40 & 45 \\
\hline 5 & 25 & 0 \\
\hline 6 & 45 & 15 \\
\hline 7 & 25 & 0 \\
\hline 8 & 40 & 30 \\
\hline 9 & 25 & 0 \\
\hline 10 & 35 & 45 \\
\hline
\end{tabular}

注. 1. 最低南空度 $20 \mathrm{cmHg}$ (一定)

2. 真空度の解節落差 $5 \mathrm{cmHg}$ (単位).

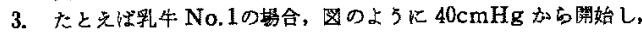
15 烈ことに $5 \mathrm{cmHg}$ ずつ低下させ. $20 \mathrm{cmHg}$ になれば, 真空 度を固定する。 No.5，7，9 は婪化しない。

実 䮖 結 果

1. 規格式の真空度制御が㩁乳速度・後控乳量・乳脂 率・乳汁中細胞数に及汪宁影響.

a. 平均控乳速度・後控乳量・脂肪率・細胞数.

(1) 第2 泰のように，手搾りHでは，平均搾乳速度㕸 高く, 脂肪率は基準量 $(3.2 \%)$ 上り高く, 細胞数住計 容量 $(50$ 万/cc) の水準であって, 目標の一つに達して いるものと推察される。(2) 三相式制御グループでは平 均搾乳速度がおそく，後㩁乳量とそれの全乳量に対する
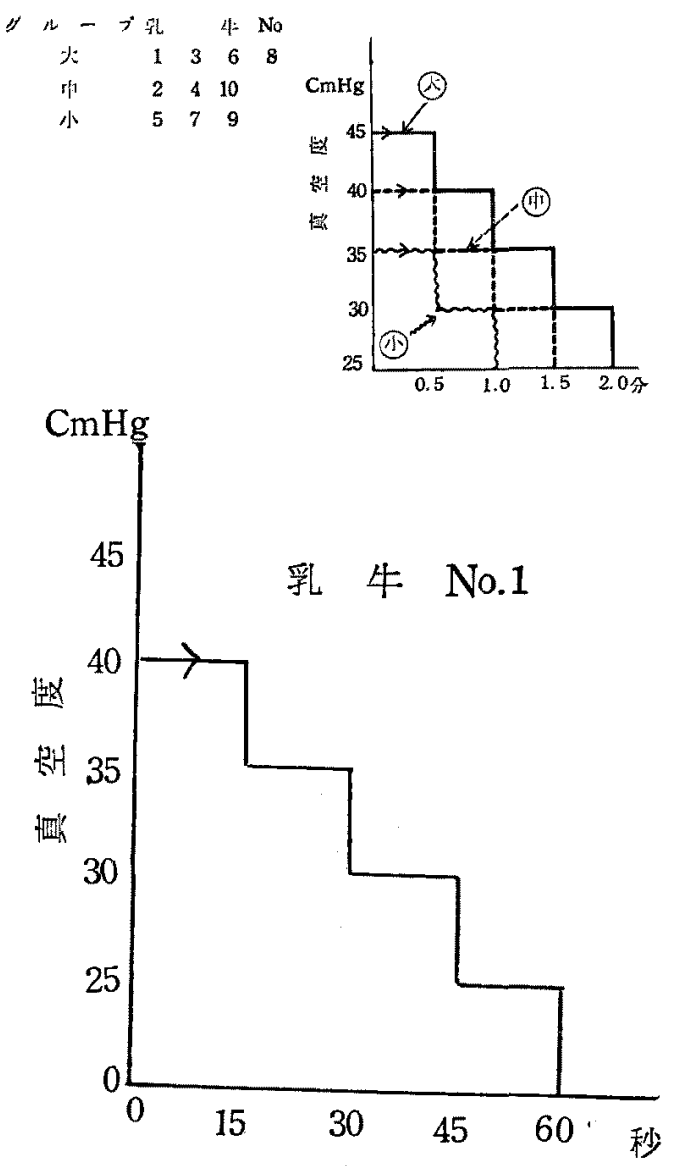

第2図 グルーブ別ポジティプ制御の調節法 比察 (後搾菜) が高かつた。三相德動のポジティプ制御 $\mathbf{P}^{\prime} \mathrm{F}$ では，脂肪率は基準量より高からつたが，細胞数は 計容量より多く，200万/cc以上であつた。(3) 二相搏動 の変圧グループでは，ボジティブ制御方式 R.F の機械

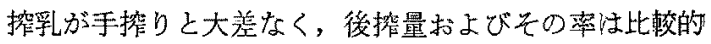
低く，脂肪率は基準量をより高くやや良好な結果を示し た。（4）真空度固定方式 C V とネガティブ制御方式 N F

第 2 表 規格式制御の総合結果

\begin{tabular}{|c|c|c|c|c|c|c|c|c|c|}
\hline 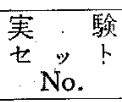 & 搏 動 相 & $\begin{array}{l}\text { 制御方式 } \\
\left(\begin{array}{cc}ホ シ ゙ ・ \\
\text { ホ }\end{array}\right.\end{array}$ & $\begin{array}{c}\text { 平均搾乳 } \\
\text { 速 } \\
\mathrm{g} / \text { 隻 }\end{array}$ & $\begin{array}{c}\text { 本搾乳量 } \\
\mathrm{g}\end{array}$ & $\begin{array}{c}\text { 後控量 } \\
\mathrm{g}\end{array}$ & $\begin{array}{c}\text { 総摔乳量 } \\
\mathrm{g}\end{array}$ & $\begin{array}{c}\text { 後 搳 率 } \\
\%\end{array}$ & 脂 肪率 & 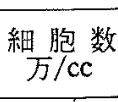 \\
\hline 1 & 控 & $\mathrm{H} \cdot \mathrm{M}$ & 991 & 4900 & & 4900 & 0 & 3.67 & 57 \\
\hline 2 & $\begin{array}{l}\text { 三 } \\
\text { 相 } \\
\text { 式 }\end{array}$ & $\begin{array}{l}\mathrm{P}^{\prime} \mathrm{F} \text { 㷎 } \\
\mathrm{C}^{\prime} \mathrm{V} \text { 定 } \\
\mathrm{N}^{\prime} \mathrm{F} \text { 亲ガ }\end{array}$ & $\begin{array}{l}537 \\
447 \\
443\end{array}$ & $\begin{array}{l}3630 \\
3500 \\
3100\end{array}$ & $\begin{array}{l}1600 \\
1200 \\
2770\end{array}$ & $\begin{array}{l}5230 \\
4700 \\
5870\end{array}$ & $\begin{array}{l}30.6 \\
25.6 \\
47.2\end{array}$ & $\begin{array}{c}(3.70) \\
3.40 \\
3.00\end{array}$ & $\begin{array}{c}(221) \\
52 \\
119\end{array}$ \\
\hline 3 & $\begin{array}{l}\text { 言 } \\
\text { 想 } \\
\text { 式 }\end{array}$ & $\begin{array}{l}\mathrm{PF} \text { ポジ } \\
\mathrm{CV} \text { 定 } \\
\mathrm{NF} \text { 亲ガ }\end{array}$ & $\begin{array}{l}870 \\
630 \\
597\end{array}$ & $\begin{array}{l}4170 \\
3600 \\
3900\end{array}$ & $\begin{array}{l}733 \\
667 \\
833\end{array}$ & $\begin{array}{l}4903 \\
4267 \\
4733\end{array}$ & $\begin{array}{l}14.9 \\
15.6 \\
17.7\end{array}$ & $\begin{array}{l}3.17 \\
3.07 \\
3.08\end{array}$ & $\begin{array}{r}72 \\
69 \\
159\end{array}$ \\
\hline
\end{tabular}

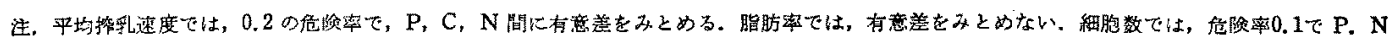
間に有意差がる。 
では，竅乳速度・後搾量・脂肪率・細胞数のいずれも， 良好な成続ではなかった。

b. 搾乳速度曲線.

(1) 手搾り $\mathrm{H} ・ \mathrm{M}$ では，最高值の1,500 18,000 g/分 のビークが0〜1分におこつた. (2) 三相搏動のポジティ ブ制卸方式 P・Hでは，ピークが最低值の $1,100 \mathrm{~g} /$ 分以 下を示し， 0〜3分までのスローカーブをつくつた。

(3) 二相搏動のポジティブ制御方式 P・Fでは, 第 3 図 のように，1,300 1,900 g/分の高水準ビークが $0 \sim 2$. 分に就きて，搾乳時間も短く，手搾りの型に接近した。

(4) 真空度固定方式 C・Vでは，ポジティブ制御方式よ りピークが低く、ネガティブ制御方式N Fで注，第 3 図 のように，どのケースよりむ低い。これは二相，三相搏 動方式ともに共通の傾向であつた。

結局, 手搾り>ポジティブ制御方式>真空度固定方式 >ネガティブ制御方式が，ピークの高さの順位となる.

二相式は，三相式よりピークが高い，

2. 個別式およびグループ式ポジティブ（正）制御が 演乳速度・後搾乳量・乳脂萃・細胞数に及ぼ卞影響

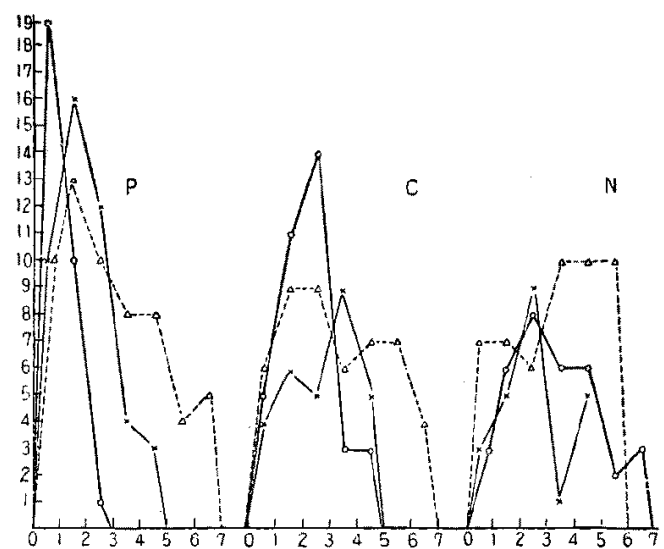

第 3 図 規格式制御の搾乳速度曲線

規格式ポジティブ制御は，大部分の埸合，撜乳速度・ 後控婆・脂肪染・細胞数に㧍いて, 真空度固定方式より まさつていることが示されたが，乳牛個々に屶析すると 必ずしも最適控乳法ではない。搾乳速度曲線をみても， 固定方式で示された個体差性，安のま規格式比例制御

第 3 表 個別式ポジティブ制御の総合結果

第 3 表 (1) 㵠乳速度（g/分）

\begin{tabular}{|c|c|c|c|c|}
\hline 搾 & 国定方式 & & 御 万 & \\
\hline $\begin{array}{l}\text { l牛 } \\
\text { No. }\end{array}$ & $\mathrm{CV}$ & PF & G F & I F \\
\hline 1 & 867 & 1333 & 650 & 925 \\
\hline 2 & 700 & 800 & 1067 & 800 \\
\hline 3 & 1025 & 860 & 1200 & 1150 \\
\hline 4 & 833 & 750 & 1133 & 800 \\
\hline 6 & 1267 & 1067 & 1400 & 1500 \\
\hline 8 & 1267 & 1025 & 1300 & 1750 \\
\hline 10 & 725 & 833 & 800 & 1150 \\
\hline
\end{tabular}

第 3 㤗 (3) 細 胞 数 (万/cc)

\begin{tabular}{|c|c|c|c|c|}
\hline \multirow{2}{*}{$\begin{array}{l}\text { 㩁乳之 } \\
\text { 乳生 } \\
\text { No. }\end{array}$} & \multirow{2}{*}{$\begin{array}{c}\text { 固定方式 } \\
\mathrm{CV}\end{array}$} & \multicolumn{3}{|c|}{ 制 御 方 式 } \\
\hline & & PF & $\mathrm{GF}$ & I F \\
\hline 1 & 270 & 230 & 600 & 150 \\
\hline 2 & 130 & 170 & 480 & 110 \\
\hline 3 & 15 & 30 & 48 & 38 \\
\hline 4 & 750 & 510 & 420 & 230 \\
\hline 6 & 100 & 78 & 120 & 86 \\
\hline 8 & 230 & 90 & 120 & 130 \\
\hline 10 & 36 & 27 & 60 & 24 \\
\hline
\end{tabular}

第 3 玟 (2) 脂肪率 (\%)

\begin{tabular}{r|cccc}
$\begin{array}{c}\text { 乳生 } \\
\text { No. }\end{array}$ & $\begin{array}{c}\text { 控乳法 } \\
\text { C V }\end{array}$ & P F & G F & I F \\
\hline 1 & 2.70 & 3.10 & 2.20 & 3.20 \\
2 & 3.40 & 3.30 & 3.25 & 3.25 \\
3 & 2.90 & 2.90 & 3.15 & 3.35 \\
4 & 4.70 & 3.45 & 4.50 & 3.75 \\
6 & 3.50 & 3.60 & 3.40 & 3.50 \\
8 & 3.80 & 2.65 & 2.70 & 2.80 \\
10 & 3.40 & 2.30 & 1.80 & 2.80 \\
\hline
\end{tabular}

第3表 (4) 結果の平均

\begin{tabular}{|c|c|c|c|c|}
\hline 搾乳法 & 固定方式 & & 御 万 & 式 \\
\hline $\begin{array}{l}\text { 測定 } \\
\text { 項目 }\end{array}$ & $\mathrm{CV}$ & $P F$ & GF & I F \\
\hline $\begin{array}{l}\text { 㩁乳速度 } \\
\text { (分/ } \mathrm{g}) \\
\text { 同比率 }\end{array}$ & 955 & 953 & 1079 & 1154 \\
\hline $\begin{array}{c}\text { 後控率 } \\
(\%)\end{array}$ & 30.6 & 35.4 & 22.8 & 21.6 \\
\hline 脂肪率 & 3.49 & 3.04 & 3.00 & 3.24 \\
\hline 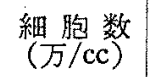 & 219 & 262 & 264 & 110 \\
\hline
\end{tabular}

注. 1. 采牛 No. 5, 7, 9 江除外してあ百。

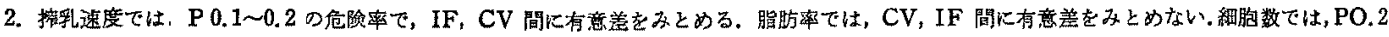
の危唤率。で有意差をみ々かる。 
鈴木

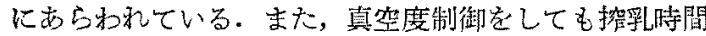
が長いケースがでている。これは，制御方式が乳牛個体 差定眎視した規格式であるためと推測される。したが的

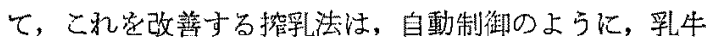
の個体别にちがつた型の真空制御方式をあたえることに よつて，得られるであるらこてれが個別式ポジティブ制 御（略称ＩＦ）である．さらに，控乳速度の曲線型から グループ別にしたのが，グループ別ボジティプ制御（G F) である. 比較対照としては, 真空固定方式 (C V)
と規格式比例制御（P F ) とつた。

a. 㩁乳速度.

(1) 第3 輚110上うに, 乳牛No. 1 では, I F はPF より非常に少なく， GF注，さらに少なくてCP以下を なつている。乳牛No. 2では，GFが最高で，I F は P Fに劣らず，CVよりを参い，乳牛No. 3では，GFを IFが，CVやPFより多い。乳牛No. 4 でも，GFが 最高レベルで，I F とCVがこれに次ぎ，PFが最も少 ない.乳牛No.6特よびNo.8になると，I FとGFが

$1000 \mathrm{~g}$

第4 図 個別式ボジテイプ制御の窥乳速度曲線（分速）
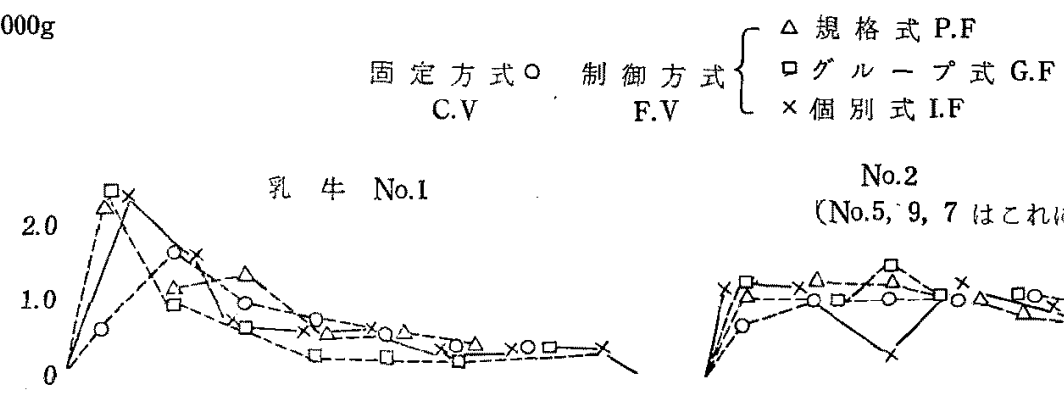

No. 2

(No.5,9, 7 はこれに準ずる)

2.0

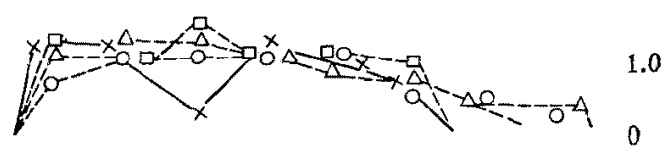

$\begin{array}{llllllll}0.5 & 1.0 & 1.5 & 2.0 & 2.5 & 3.0 & 3.5 & 4.0\end{array}$

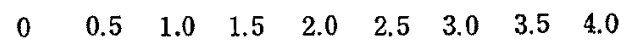

$1000 \mathrm{~g}$
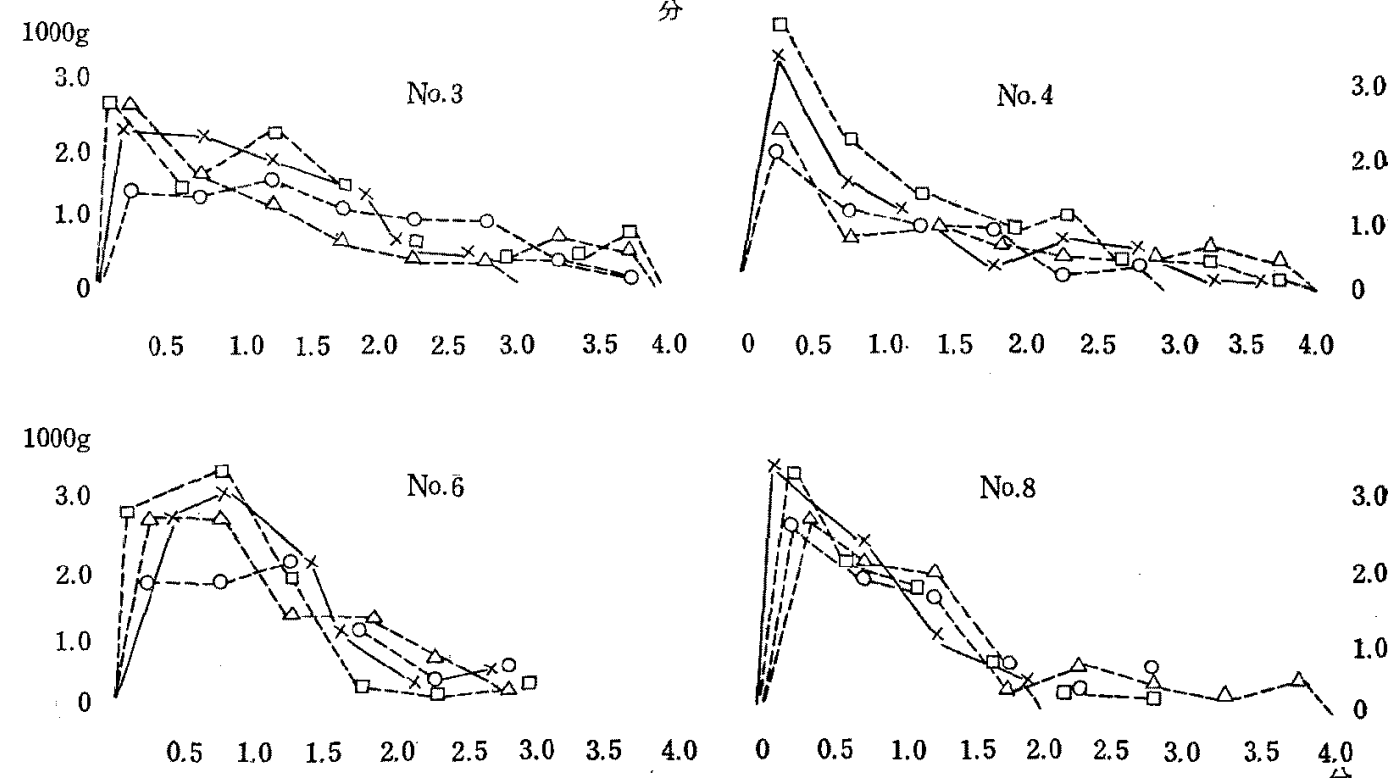

$1000 \mathrm{~g}$
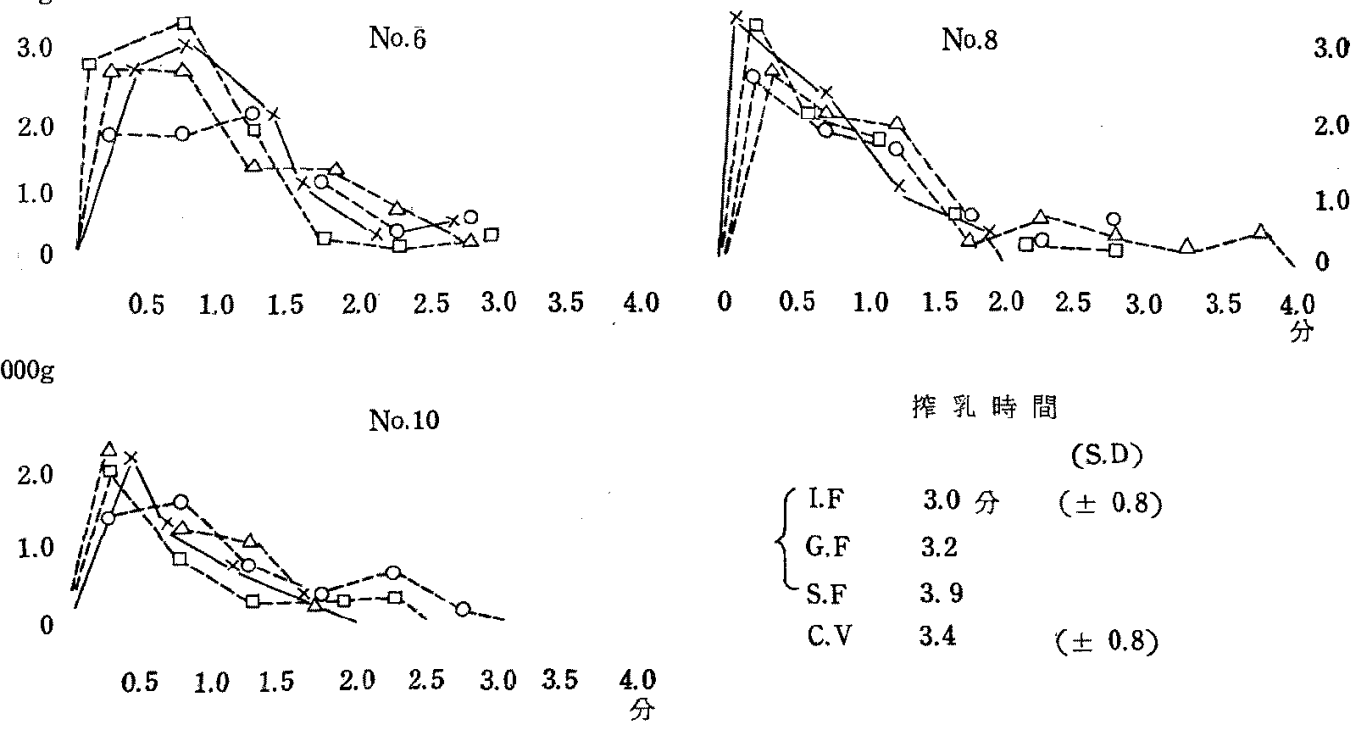

揩乳時間

$$
\left\{\begin{array}{lll}
\text { I.F } & 3.0 \text { 分 } & ( \pm 0.8) \\
\text { G.F } & 3.2 & \\
\text { S.F } & 3.9 & \\
\text { C.V } & 3.4 & ( \pm 0.8)
\end{array}\right.
$$




\section{機械擦乳の真空度制御之勃萃・乳筫}

トップグループで，C VやP Fをひきはなしている，と くにNo. 8では，最高部録を示している. 乳牛 No.10て も，IFがリードし，PF， GF，CVのグループに差 をつけている.

（2）以上の結果，実験乳牛 7 頭中，平均速度でI F が 最高水準定形成しているのは No6，8，10，G F 多最高 水準にあるものは No.2，3，4 である。このほかＰＦ性 No. 1で最高で亦るが，CVはどの乳牛でも低い，平地 值としては第3表(4)のようにI Fが最高水準に達し, 全 体怯 I F, G F , PF， CVの順になつている。

b 控乳速度曲線.

(1) 第4 図の上うに，No. 1 以標準の指数曲線型で好 つて, $0 \sim 0.5$ 分に $2,000 \sim 3,000 \mathrm{~g}$ /分（以下 $\mathrm{g} /$ 分の路 位定略す)のピークが，I F， G F扎よびP F の制御グ ループによつてつくられ，0.5 1.0 分に 1, $500 \sim 2,000$ のピークがCV汇よつて現るれる。乳牛No.1では，控 乳時間は，PFが 3 分で最も短く， GF と C Vが 3.5 分 でこれに次ぎ，IF No. 2 では, 全方式とも 1,000に平均化，ピータ定つ くらず，半棈円形を示すが，IF方すしら $1 \sim 1.5$ 分に 潜伏期比近い谷底它つくつている。㩁乳時間は，GF

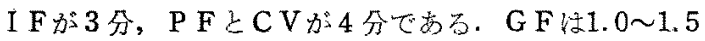
分に 1,500 のゅるやかな型を示している。

乳牛 No. 3 では，PF， GF，I Fの制御グループが $0 \sim 0.5$ 分に 2,000〜3,000のピークをつくつているが, CVはほるや加な型で，1.0〜1.5分に 1,500のピーク定 示す。撞乳時間は，I Fが 3 分， GF と CVが 4 分であ る. 乳牛No. 4 でも，0.5分以内に $3,000 \sim 3,500$ のピー クが $\mathrm{GF}$ およびIFによつつくら秃，PFと CV は 2,000 前後となつている. 䆣乳時聞汪，逆にC Vが 3 分 で，その他が 4 分となつている。

“乳牛No. 6 性，正規曲線型と指数曲線型との中間タイ プに属する．0.5〜1.0分で， GF抢よびIFが3,000前 後に, P Fが2,000にピーク完つくる。CVは1.0〜1.5 分のずれたタイミンダで，2,000のピーク定形成寸る. 摧乳時間は，両者ともに 3 分である。乳牛No. 8 では, 0.5 分以内に, I Fおよび $\mathrm{FF}$ が 3,000 3, 500 のト。 プピーク家つくり，これについでP FおよびC Vが2, 000 のピーク亦す。搾乳時間は，IFが 2 分で最む短く， $\mathrm{GF}$ と CVが 3 分， $\mathrm{PF}$ 出 4 分となつている.

乳牛 No.10でも，PF，I F, GF 法，0.5 分以内绍 2,000〜2, 500 のピーク它，CVは $0.5 \sim 1.0$ 分に 1, 500 のゅるいピーク示している.控乳時間は，PFとIF が 2 分で最も短く， GFが 2.5 分， CVが 3 分である。

(2) 以上の結果定をと好ると，I FとGFが最初
○2,000 4,000 を示しているのは, 乳牛 No. 1, 3, 4, 6,8 および 10 で, P F が最高のもの恃, 乳牛 No. 1，3 および 10である。CVが最高のもの惊はい，乳牛No.2 はピークを形成しないので，CVに似た掉乳達度曲線の タイプをとり，制御奻果を示さなかつた。乳牛No. 5, 7

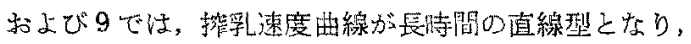
制御が有効でないので，比較されない，事た摧乳持間が 最短であつたのは，I Fで乳牛No.1，2，3，8和よび 10, GFではNo.2, P FではNo.10, CVでは No. 4 である。全方式が同等なのは No.6である、評洒順位法

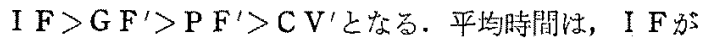
3.0 分で最短. GFが 3.2 分でこれに次ぎ， CV が3.4 分, PFが.3.9 分で最長である。結局, 㩁乳時間は, 短 いほうから IF, GF, CV, PFの順となる。

c. 脂肪率.

(1) 第 3 表(2)0ようk，乳牛No.1で蛙，IFが基 準量3.2\%に達し，PFが3.2\%弱でこれにつぎ，GFと CVがと舟に $2 \%$ 台である。乳牛No. 2 では，全方式が 基準量以上になり，とくにCVが多い，乳牛No. 3 で性 I Fだけが基準量越え，GFがこれにつぎ，PFとC Vは3\%以下である.乳牛 No.4ではGF と CVが翼常 に多く，4\%以上の最高記録定示し，他も基準量より多 くて, I F, PFO順になる。乳牛No. 6 で, 全部基 準量以上で，3.4 3.6\%にあつをつているが，PFは比 較的多い. 乳牛 No. 8 では, とく沉多いのがC Vで, 他 は2.0 3.0\%走し，PF㵊少である. 乳牛 No.10で

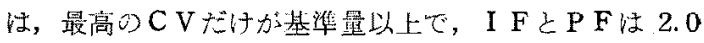
〜3. $0 \%$, G F は1.0〜2.0\%である.

(2) 以上の結果，第3 表(4)の上うに，乳脂率が高加 た方式は C V で乳牛 No.2，4，8，放よど10 とみられ る. これにつぐのはIFでNo. 3 にみられ，さらにPF はNo. 6 にみられる。 GFは，いずれにも認められな

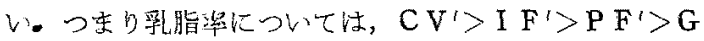
$\mathrm{F}^{\circ}$ の順となる. 基準量3.2\%以上定す力式㹥，5頭で IFで，同じく 5 頭でCVとなつて，No. 2，4，6，8， 10でトップダループをつくり，3頭で法 $\mathrm{GF}$ および $\mathrm{PF}$ となつて，これに次ぐダループをつくり，結局 I F > C

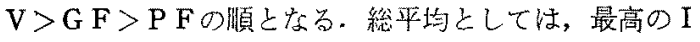
$\mathrm{F}$ と，第 2 位の $\mathrm{CV}$ が基淮量以上を示し， $\mathrm{GF}$ と $\mathrm{PF}$

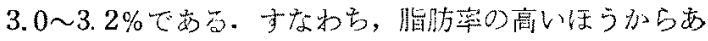
げれば，CV，IF，PF， GF心順となる。

$\mathrm{d}$ 細 胞 数.

(1) 細胞数は，第 3 表(3)のように，乳牛 No.1では， 計容量 50 万/cc（以下，単位万/cc 略す）より，全方 式とも多く，I Fは100台，PFとCVは200３00，G 
Fは最大となつている。乳牛 No.2では，全方式で計容 量老こえ，100〜200の範国で，I F，C V，P F の順之 なり，GFはやはり最大である。乳牛No.3では，逆に 全方式已も許容量以下となり，CV，PF，IF， G F の順に多くなつている.乳牛No.4では, 詐容量よりも 異常に多く, 200 8000籍国にあり, I F, GF, P F C Vの順で多い.

乳牛 No. 6 では，全方式で許容量より多く，99以下が $\mathrm{PF}$ と I F , 100 以上が CVとGFである. 乳牛 No. 8 では，やはり全方式が許容量以上で，100 以下が P F， $100 \sim 200$ がG F とI F，200以上がC V となつている. 乳牛No.10で注, 許容量以下がI F, PFおよびC Vで 以上がGFである。

（2）以上の結果，第 3 表(4)のように，全方式とも許容 量50以上となつているのは, 乳牛 No. 1，2，4，6 拉よ び8，全方式とも許容量以下となつているのは，乳牛 No. 3招よび10である。すなわち個体差が大きく，方式 の差将小さいるのと推定される。最小值注，IＦとなつ ているのが乳牛 No.1，2，4 および 10，P F となつてい るのが No.6および 8，CVとなつているのが1頭で， GF 1 頭もない。細胞数が少ない汪うからい充ば，I $\mathrm{F}, \mathrm{PF}, \mathrm{CV}, \mathrm{GF} \mathrm{F}^{\circ}$ の順となる。総平均では，全方 式とも許容量以上で，I Fだけが 100 台，CV，PFお よびG Dは200 台となっている.

e. 後㩳率 (全乳量に対する後搾量の比率).

この率からいえば, $20 \%$ 台の G F, I F と，30\%台の PF， CVという二群に分か机る. 第3表(4)では，IF $\mathrm{GF}, \mathrm{CV}, \mathrm{PF}$ の順となつている.これは, 絶対的許 容量が判明しないので，相対的な比較しかできないが， ここでも，個体別あるい性グループ別のポジティブ制御 が良好な結果をしめしている。

\section{考察}

今名ら 100 年以上も前に発明された搾乳機は, 単相式 (吸引過程のみ)であつて，控乳量が貧弱な上，生理的 にも安全でないものであっだ。

しかし, 西ヨーロッパで, 二相式（吸引・正縮過程） 功考案されるに㧍よえで，近代掟乳機の基濋ができ，控 乳速度が比較的はやく, 乳量・乳質からみても, べつに 悪くないシステムに改良されて，アメリカにる普及発展 した，この䀪合，圧縮過程による乳頭へのマッサージ刺 激が，乳の排出を促進し，また真空の連続的作用を抑制 主るメカニズムになつているものと推諭される。

しかし，この二相搏動式でも，真空度をたかめると， 搾乳速度は山やくなるが，後控乳量（手搾りによる）が かえつてふえることが，新しい問題となつた。 BAXTER $^{61}$
SMith and PATERSEN" 狩よび STEWART ${ }^{8)}$ は, いずれも $25 \mathrm{cmHg}$ 加 $52 \mathrm{cmHg}$ まで，真空度の增大にともなつ て、搾乳速度はたしかにはやくなるが, $36 \mathrm{cmHg}$ 以上の 真空度になると，後控乳量が多くなるという実験結果を 報告している. DODD and CLOUGH ${ }^{21}$ は, $25 \mathrm{cmHg}$ 加ら $64 \mathrm{cmHg}$ まで，比例的に控乳速度がはやくなるが，後控 量も加速度的に多くなること定実証しているこの傾向 は，本報の害験成續と一致する。

本来，機珹㩁乳のあとで後竹りが必要之なる原因㤝， 控乳終期にティートカップがはいあがり現象 (Creeping up）を和こし，乳頭基部它しめつ汀るので，乳の流出が さ先なげられることにあると推定されている。これを機 樥的に改良するため，ペイルを乳牛体につりさげ，乳の 重量によつて，この現象定防止するサスペンド型が考案 された. TURNER ${ }^{10)}$ は，この方式を推奨している．著者ら

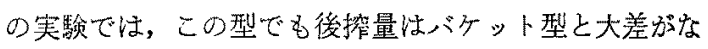
いi1)。しかる，サスペンド型でも真空度をたかめると， 後搾り量が多くをることは, バケット型と共通の短所で

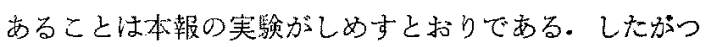
て，サスペンド型だけでは，根本的な解決はできない。

さらに，高真架度方式が乳房炎をなこしやすいことは 多くの研究者12-20) が報告している.乳房炎まで進行し

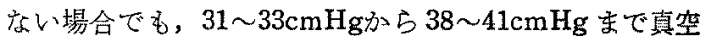
度坴高めると，牛乳中心塩分叔よび白血球がらえるとと

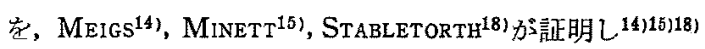

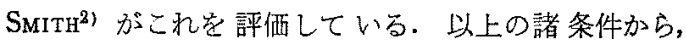
WHITTLESSTONE21) らは，真空度を $38 \mathrm{cmHg}$ にとざある ことを主張し、SMITH は，むしろこれ以下に真空度をさ げることが世界的傾向であると述べている゙2.

しかし反面, 低窝空度方式が控乳速度を遅くすること は，普遍的法則であり，KNODT ${ }^{22)}$ 打よび WARD and $\mathrm{SMITH}^{28}$ が，オキシトシン（乳汁排出ホルモン）の作用 限界時間定 8 分と実験的に推定しているので，乙れ以上 になると，合理的でない，本報の实験でも，低真空度の 場合に，か六つて後搾乳量が多くなつていることは，長 時間揬乳のためと想像される。しかし，欧米の各研究者 の実験とは一致しないので,これは今後の研究㦗題とし て残されている.

一方,ソ戛と東ヨーロッパでは，二相式の生理的悪影 響老とり除くため，休息過程を加えた三相式（吸引・圧 縮・休息過程）究考案し，実験的研究をすすゆている。 しかし三相武法，理諭上当然で方るが控乳速度が遅く， 本報の実験でも，限界時間を越えている. MARTSUGIN らも，この点老認めているが，反面，乳房炎の発生率は 二相式で $12 \%$ ，三相式で $4 \%$ であることを証明し，後者 
の生理的安全性觉評洒している。本報り実験でも，三相 式は，後站乳量・脂肪率・細胞数などに対して悪い影響 がないので，宽全な点は否定できない，しかし低効率と 安全性とを合わせて考光れば，三相式の効果は相殺され てしまう

以上，研究史的に及て，二相式注高速㩁乳，三相式法 安全焪乳であるが，総合的にみると，いずれも単独では 最高剂率の最適搾乳法とはいえない。

本報の真空度制御方式は，この矛盾荌解消与当のに有 勃であるう.この実用考案は, 農業機械の研究者之, 製 作者によつて, 別個に研究されている。

最近, 欧米でも Controlled milking が強調され, 大 規模経営で, 乳牛集団ごとに最適の真空・搏動方式を適 用することがすすめられている。また，PERKINS24) らに よつて, 㩁乳機の自動調節 (Automatic Control) 方研 究されている.しかしこれらは，真空度固定方式を前提 てした調節法であつて，本報でいら制御方式ではない。

$$
\text { 要 約 }
$$

乳牛において, 最高効率の最適㩁乳を行なうため, 真 空度制御方式堂とりあげた。この方式が，必裂で十分な 条件を䚚えているかどうが，徒来の真空度固定方式学 禋準対照として実験した。 その結果つぎの知見它得た。

（ただし，乳脂率の基準量は $3.2 \%$ ，乳汁中の細胞数の 最大許容量法 50 万/ ccとする。）

1. 三相搏動の真空制御う式：ポジティブ (正) 制御 方式は，ネガティブ（負）制御方式より，搾乳速度がは やく, 脂肪率が高いが，後搾率と細胞数は適正でない。 一般に，二相搏動の真空制御方式上り，㩁乳速度がお去 w.

2. 二相搏動のネガティブ制御方式（以下二相搏動式 乙呼ぶ）：ポジティブ制御および真空固定方式より，控 乳速度がはやく，脂肪率は悪くないが，後控率と細胞数 は必ずしもよくないし，また必ずしも咕正ではない。

3. 規格式のポジティブ制御方式：これは，乳牛の個 体差を無視した方式である。㩁乳効率方よび速度は大き く，細胞数・後擦率・脂肪率注必ずし悪くない，

4. 乳牛グループ別のポジティブ制御方式: 乳牛グル 一プを，搾乳速度曲線心型別に分類して制御する方式で ある、㩁乳の効率および速度と後㩁率は，規格より高い が，脂肪率と細胞数は必ずしむまさつていない。

5. 乳牛個体別のポジティブ制御方式：乳牛個体ごと に固有の制御方式を与えるるのである。他の真空固定・ 制御方式に比べると搾乳速度は最むはやく，後控率と細 胞数法比較的低いが脂肪率は必ずしも低くない，

この研究について, 尃門的指導定うけた東京大学家畜
育種学教室の内藤元男教授, 同農業機械学教室の安田与. 七郎助教授, 農林省畜産試験場生理科の五島孝技官, 機 械製作に協力された共栄精機製作所，本多製作所，宫本 製作所, 乳質分析に協力された森永乳業之明治乳業の雨 株式会社各工場，㩁乳作業を担当された実歌委託牧場 （酪㟽電化センター，小泉・牧・石井の各牧場）心心汃ら 深㛛する。

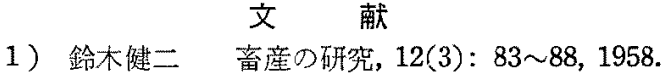

2) Sмiтн, V. R. Physiology of Lactation, lowa., p. 161, 1959.

3) Dodd, F.H. and P.A. Clough Machine Milking, London, p. 5, 1957.

4) Martsugin, D.D. Report No. 1, Zootechnical science in U.S.S.R., vol. 5, No. 5, 1950.

Martsugin, D.D. Report No. 2, ibid., vol. 3 , No. 7,1954 ; vol. 27 , No. 3 , p. 339 343, 1957.

5) Whittlestone, W.G. The Principles of Mechanical Milking, Sidney, Sections 1, 1 1.2, 1960

6) Baxter, E. S., et al. J. Dairy Res., 17: 117, 1950.

7) Smith, V.R. and Petersen, W.E. J. Dairy Sci., 29: 45, 1946.

8) Stewart, W.E., et al. ibid., 41: 849, 1958.

9) DoDD, F.H. and P.A. Clough Machine Milking, London, p. 5 6, 1957.

10) Turner, C.W. Machine Milking Efficiency, Ottawa, part 4, 13, 1960.

11）鉿林健二 畜産の研究, vol. 12 , No. $12,1958$.

12) Jofnson, S.D. Cornell Vet., 34: 99, 1944.

13) Leslie, A. and W.G. Whittliestone Imp. Bur. Dairy Sci., 1939.

14) Meigs, E.B., et al. U.S.D.A. Tech. Bul., No. 992, 1949.

15) Minett, F.C. J. Am. Med. Ass., 106: 1213, 1936.

16) NEave, F.K., et al. J. Dairy Sci., 36: 504, 1953.

17) Rose, V.T. Vet. Med., 38: 14, 1943.

18) Stableforth, A. W. Agr. Progress, 15: 8, 1938.

19) Stevenson, W. G. Canad. J. Comp. Med. Vet. Sci., 10: 115, 1946.

20) Watrs, P.S. Vet. Rec., 54: 181, 1942.

21) Whittlestone, W. G. The Principle of Mechanical Milking, Sidney, p. 8 16, 1960.

22) Knodt, C.B., et al. J. Dairy Sci., 32: 637, 1949.

23) WARD, G.M. and V.R. SmIth ibid., 32: 17, 1949.

24) LANG, F. Dairy Sci. Abst., 20: 2, 1958. 


\title{
Résumé
}

\section{The Influence of the Vacuum Control of Machine Milking Upon Milking Efficiency and Milk Quality in Dairy Cows}

\author{
Kenji SuzUKI \\ (Department of Animal Breeding, Faculty of Agriculture, University of Tokyo)
}

The present study was carried out to find out the most suitable vacuum control of milkingwith the highest efficiency and optimum milk quality.

The results of the various types of vacuum control were compared with those of the ordinary constant vacuum control and those of hand milking on such items as milking efficiency, maximum rate, butter fat percentage, cell counts in the milk, and stripping percentage.

1. Positive and negative vacuum control in the three-phase system: The maximum rate and fat percentage were higher in the positive control than in the negative control, but the stripping percentage and cell counts were contrary. In general, the maximum rates were lower in the three-phase system than in the ordinary two-phase system.

2. Negative vacuum control in the two-phase system: The maximum rate was lower in this control than in the positive and the ordinary constant vacuum control. The fat percentage was not so low, but the stripping percentage and cell counts were almost the same among these types of control, and any of them was out of the standard quality.

3. Positive feed-back vacuum control in the two-phase system: This system is to control vacuum positively by the variate rate of milk flow, regardless of the individual rate. The milking efficiency and maximum rate were higher in this system than in the ordinary constant vacuum. The cell counts, stripping percentage, and fat percentage were almost the same between the two systems.

4. Positive feed-back vacuum control in accordance with the rate of a given group of cows in the two-phase system: This system is essentially the same with the system mentioned above, except that the rate of controlling vacuum is adjusted by the milk flow in a given group of cows. In this system, the milking efficiency, rate, and stripping percentage were higher than in the ordinary system, but the fat percentage and cell counts were similar to. those in the latter.

5. Positive feed-back vacuum control in accordance with the rate of a given individual cow in the two-phase system: In this system, the vacuum is controlled individually according to the milk flow. The maximum rate was the highest of all the systems examined. The stripping percentage and cell counts were comparatively low, and the fat percentage was almost similar.

6. In conclusion, the positive feed-back vacuum control system of various types is superior to the ordinary constant vacuum control, having high milking efficiency and optimum milk quality. Under the ordinary constant vacuum control in the two-phase system, the milking rate is not so low, but the milk quality is apt to be below the standard. The three-plase system shows not with standing lower milking efficiency and better milk quality than the two-phase one. Both systems include contradictory factors for milking and fail to indicate both high efficiency and optimum milk quality. 